\title{
WATER FACTS FOR OKLAHOMA
}

BY

UNITED STATES

GEOLOGICAL SURVEY

JANUARY 1, 1945
Review of the present progrom for obtoining woter tacts

Discussion of the functions and shortcomings of avariable water facts

Progrom with annual costs for obtaining adequate water facts on the quantity, occurrence and quality of the surface water and ground water supplies

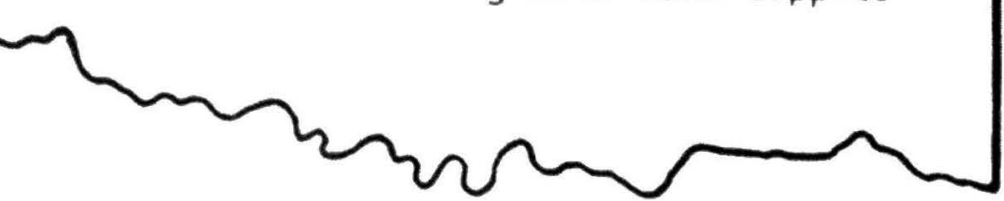

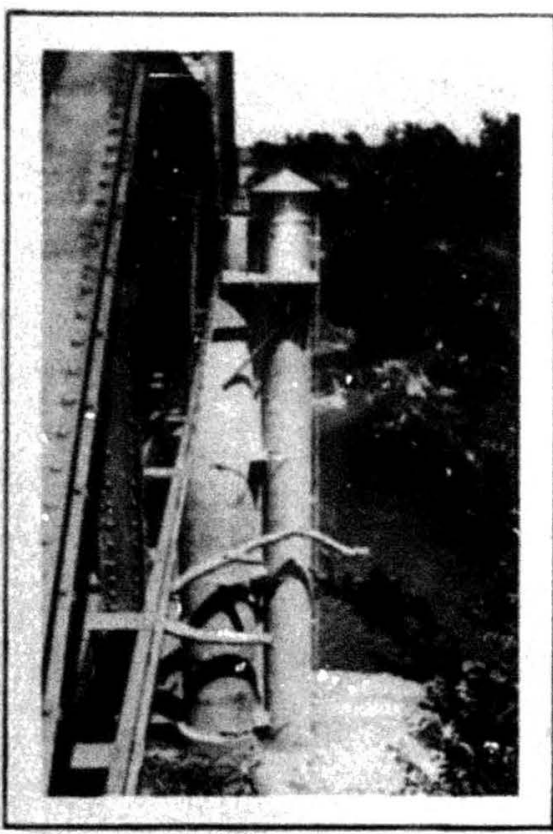

Surface Water

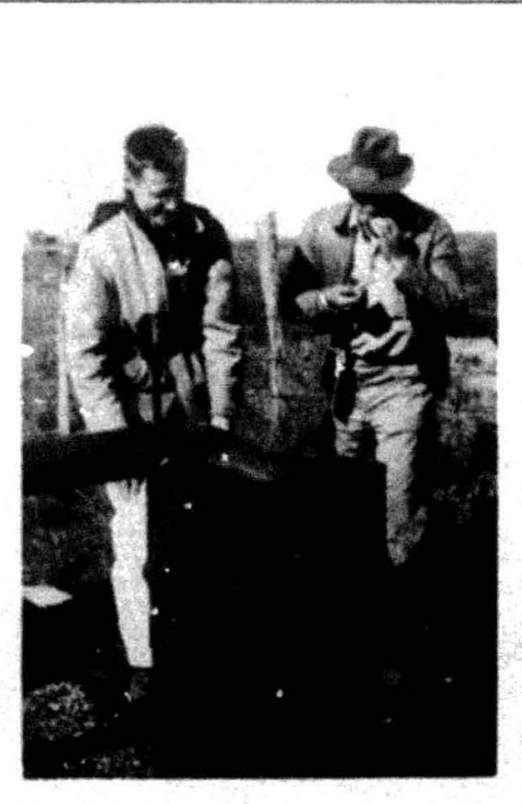

Ground Water

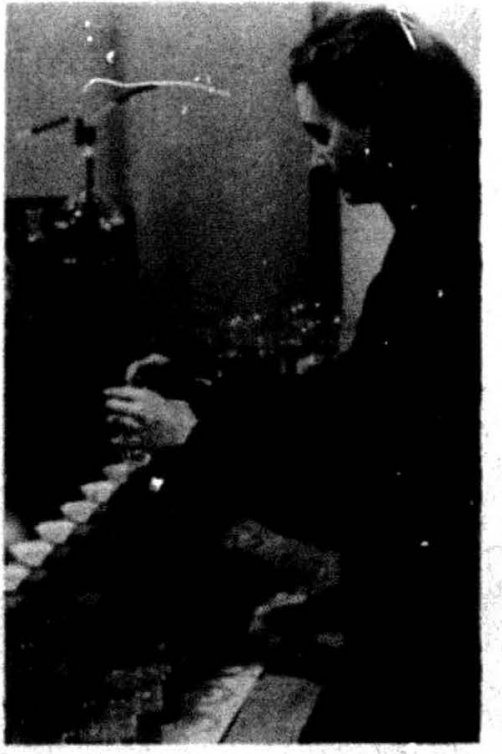

Quality of Water

Accumulation of Water Facts

can be the means of transforming

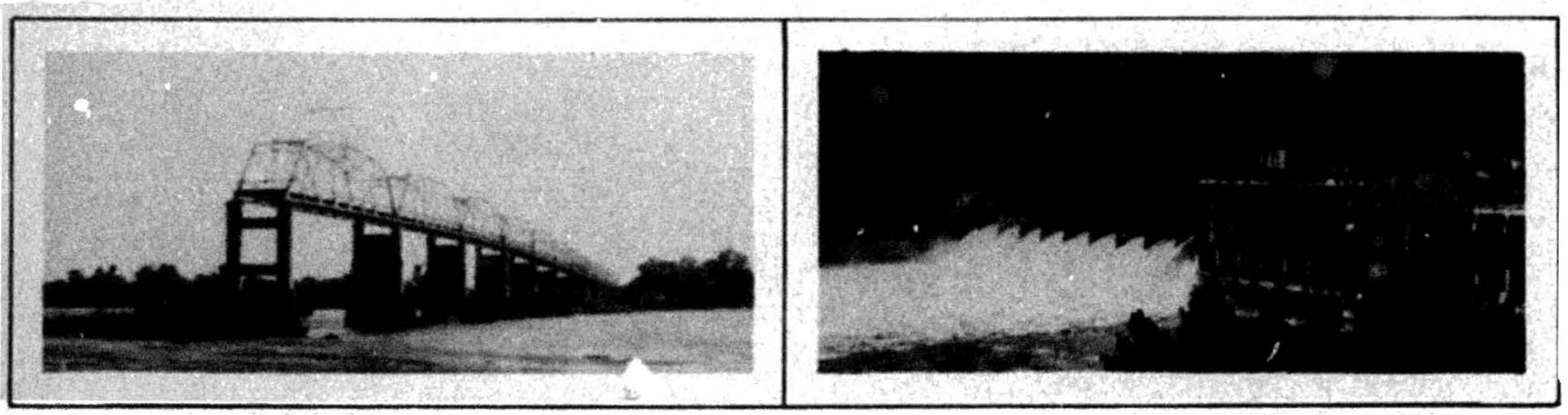




\section{UNITED STATES \\ DEPARTMENT OF THE INTERIOR \\ GEOLOGICAL SURVEY \\ Washington 25, D. C.}

December 26, 1944.

Mr. Don McBride, Chairman,

Oklahoma Planning and Resources Board,

Oklahoma City, Oklahoma.

Dear Mr. McBride :

Transmitted herewith is a copy of a report entitled "Water Facts for Oklahoma." Delivery of this report to you meets one of the principal objectives of investigation of the availability of water for industrial use in the State of Oklahoma, now being conducted cooperatively between the Oklahoma Planning and Resources Board and the Geological Survey. The report suggests a program for continuing and expanding our co-operative water-resources investigations, and is designed to guide State and Federal officials in their recommendations therefor.

It is quite satisfactory to the Geological Survey if you wish to publish the report for distribution in the State.

Your ad rice and assistance in the preparation of this report, as well as those of other State representatives, are gratefully acknowledged.

Very truly yours,

W. E. WRATHER, Director.

Enclosure 500 


\section{CONTENTS}

Introduction - -

Supply of water in Oklahoma_... S

Knowledge of water facts........ 6

Deficiencies and shortcomings in water facts

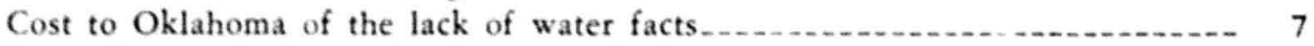

Role of water in future development of Oklahoma_..... 8

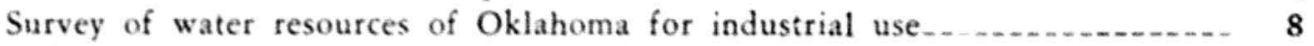

Federal-State cooperative investigations......... 8

Surface Water .............. 10

Present program...................... 10

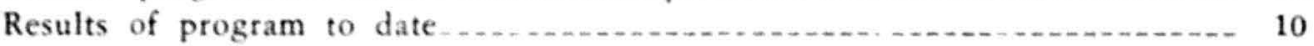

Stream-gauging program of the Corps of Engineers $\ldots$

Importance of continuity, length and areal coverage of records ............ 11

Need for information for reduction of losses in storage ................ 11

Value and use of information on maximum stages_............... 12

Losses of water from channels................... 12

Records on streams near State boundary to safeguard rights of Oklahoma_... 12

Comprehensive program ............. 12

Map of Oklahoma showing location of existing and proposed

stream-g2 ging stations, Figure 1_...

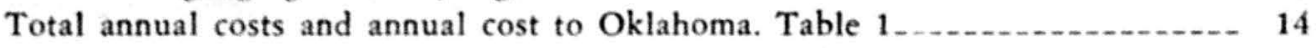

List of existing stream-gauging stations in Oklahoma, Table 2 $\ldots \ldots \ldots \ldots$

List of proposed additional stream-gauging stations

in Oklahoma, Table 3 3

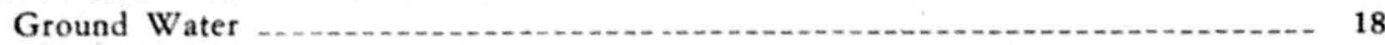

Review of program to date....

Map of Oklahoma showing areas in which cooperative investigations

have been made since 1937 or are in progress, Figure $2 \ldots 20$

A comprehensive program ............ 21

Pollution and contamination of ground water

Map of Oklahoma showing location of existing observation wells, Figure 3_... 23

Ground-water law _........... 24

Registration of water-well drillers

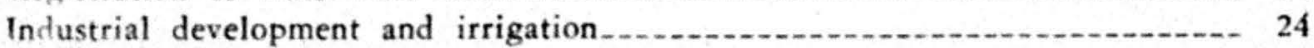

Special projects

Total annual costs and annual cost to Oklahoma

Quality of Water

Quality of surface waters_........... 27

Sediment loads _....... 29

Quality of ground waters_.......... 30

Industrial utility of public water supplies_....... 32

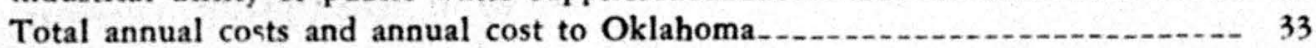

Total annual costs and annual cost to Oklahoma

Water Utilization $\ldots \ldots \ldots$ 


\section{WATER FACTS FOR OKLAHOMA}

Oklahoma is endowed with many valuable natural resources, but waterthe one most essential to man-has been so bestowed by Nature that its use must be wisely and carefully planned if its fullest benefits are to be realized. Such planning must be guided by records of the past because it is impossible otherwise to forecast, with any assurance, water supplies. Continuous and systematic records of surface and ground waters extending over many years are necessary for the evaluation of the averages, extremes, and variations in the quantity, occurrence, and quality of supplies from all sources.

Because such records are not now available, projects may be designed, constructed, and operated on the basis of information which is generally decidedly deficient in many respects, thus leading to indifferent success, partial failure, or actual loss. Industrial projects, if planned on the present records, must be designed on meager information concerning the adequacy and suitability of the water supply, surface or ground, for their special requirements. They may lack information of such important factors as maximum flood stages to be protected against. Municipalities may seek water from surface streams or from wells with insufficient knowledge of the quantity and quality of the supplies to give proper assurance of success.

Undoubtedly the almost total absence of adequate records has in many cases delayed the starting and completion of sound projects with attendant losses to Oklahoma in indeterminate amounts of benefits that may be derived therefrom. The indefinite continuation of such losses can be largely prevented by the prompt accumulation of adequate water records. The present program for obtaining information about water has been too limited in scope and too short in duration to provide adequate records. The United States Geological Survey, which has been investigating the water resources of the Nation since 1889, is cooperating with the Division of Water Resources of the Oklahoma Planning and Resources Board, the State Geological Survey, the Oklahoma Agricultural and Mechanical College, and other State agenries, in a survey of the water resources of Oklahoma for industrial use. As a part of this survey, the following "Water Facts for Oklahoma" has been prepared. These plans suggest a comprehensive program for the continuation of the present program and its normal healthy growth into one that would assure in due time an adequate accumulation of water facts. 
This comprehensive program herein described includes:

(a) An expansion of stream gauging to cover more adequately the rivers of the State in order to obtain information on small as well as large stream: as a basis for the storage of waters for industrial, irrigation, municipal and flood-control purposes. The expansion should provide for the collection of information on stream flow that is essential for control and full economic use of the surface-water resources.

(b) The investigation of the grouid-water resources which are of great importance in the State, the extent and capacity of the water-bearing geologic formations, the recovery of ground water for muniripal, industrial and irriga tion uses, the fluctuations in ground-water supplies throughout wet and dry seasons, and the integration of the ground-water supplies with surface-water supplies in order to obtain the highest values from both.

(c) The chemical analysis of both surface and ground waters to determine their fitness for municipal, industrial, and agricultural uses, and to serve as a basis for planning the treatments of such waters to fit them best for use. and the measurement of the sediments contained in s:'rface waters for use in the design of water channels and reservoirs with full allowance for reduction of capacities by silting.

(d) The preparation of reports upon the best methods of controlling and utilizing the water resources.

The adoption of a constructive program and placing it in operation at the earliest practicable time will be a means of assuring to Oklahoma the fullest benefits which may accrue from the well-planned use of its water. The cost represents only a fraction of a loss which might be prevented by the proper use of adequate water facts.

The water program described herein will cost annually:

For surface water. $\$ 75,000$

For ground water. 72,000

For quality of water (including sediment) 39,000

For utilization studies and reports 5,000

Total $\$ 191,000$

Oklahoma's half $\$ 95,000$

The suggested program may be attained by appropriate growth of the program of water investigations now under way. The expanded and additional activities contemplated by the program are suited to adoption at one time or in progressive steps, as may be deemed wise.

Detailed consideration of this program and a related program of topographic mapping follows.

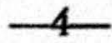




\section{Introduction}

Water descends from the clouds, and forms rivers, lakes, and seas. It is delivered to the earth absolutely free, not in accordance with man-made specifications or orders but at the caprice of the elements. Hence man to realize fully the benefits of this incomparable and recurring resource must have full knowledge of its erratic occurrence before ways and means may be devised for putting water to beneficial use and for preventing it from doing harm. Water facts are essential for the effective and efficient utility of water.

\section{Supply of Water in Oklahoma}

During the driest calendar year (1910) experienced since 1891 sufficient water fell on the State of Oklahoma to have provided each and every man, woman and child listed in the 1940 Census of Oklahoma a supply of about 26,700 gallons per day throughout the year. Unfortunately, or perhaps fortunately, Nature has first call on the water. After her "take" there would still remain, however, over 500 gallons per day for each person, or many times the average per capita consumption. Nature's take represents the consumptive use of water by vegetation and the loss of water by the process of evaporation from land and water surfaces. The residual flow after Nature's take is generally available for man's use as surface flow in the streams and as underground supplies. Although man's 'use of water may be fairly constant throughout the year, the supply of water varies greatly from day to day, year to year, decade to decade, and over even much longer periods of time. Since the beginning of official records by the U. S. Weather Bureau about 1891, the greatest rainfall recorded in Oklahom luring a 24-hour period was 15.50 inches at Sapulpa on September 3-4,, 40 , with unofficial measurements for the same storm indicating a maximum fall of more than 24 inches in a 10-hour period between Meramec and Hallett; the greatest annual precipitation observed was 80.35 inches at Watts in 1927 and the least annual observed was 8.62 inches at Boise City in 1934. Over all areas of the State receiving about 42 inches or more of rainfall Nature's take is about 32 inches. As the rainfall decreases below 42 inches, Nature's take becomes smaller until it reaches about 19.5 inches on areas receiving about 20 inches of rainfall. Although water is essentially pure as rainfall, it becomes polluted or contaminated in varying degrees, and in extreme instances it becomes unsuited for use by man vegetation or industry.

Before man can settle and prosper with confidence, he must be assured of a supply of water for his personal use, his agriculture and his industry that is adequate both in quantity and quality. Such a supply may be obtain- 
able from either surface or ground surfaces. In some parts of Oklahoma the quantity of water left after Nature's take may be small, as the average annual rainfall of 32.6, inches over the State is barely in excess of Nature's normal take and the quality of the supply may have been adversely affected by con. tact with rocks and soils; many of which are highly soluble.

\section{Knowledge of Water Facts}

Adequate knowledge of water facts in respect to the quantity, quality and occurrence of surface and ground waters can only be obtained through a comprehensive program of systematic observations extending over long periods of time. Information so obtained is indispensable as it represents the first step in transforming water from a poor master into a good servant. This information is essential for the preparation of adequate plans and designs for projects involving flood control, supplies of water for industrial, domestic and agricultural uses, control of pollution and contamination, control of depletion of ground-water supplies and other uses.

Since it is impossible to forecast with assurance the behavior of water at any time in the future, it is necessary that plans be made for the future on the basis of the experience of the past. To gauge accurately the experience of the past, many years of continuous systematic records are essential so that the averages, extremes and variations may be properly evaluated. If such records had been available, properly appraised, and used in designs and plans, it is confidently believed that the failure of many projects involving the use and control of water could have been prevented. Thus a relatively small expenditure of funds to obtain these records might well have been and in the future may be the means of saving countless dollars and many lives.

\section{Deficiencies and Shortcomings of Water Facts}

Studies by various Governmental agencies as late as 1941 have disclosed that there were at that time no usable continuous records of discharge longer than 18 years on the Red River and its tributaries in Oklahoma and only three records were 10 years or longer. These short and intermittent records prevented entirely some essential studies on the tributaries and greatly handicapped others. Stream-flow records had to be supplemented by estimation of runoff from rainfall. This deficiency of stream-flow data is so great that little or nothing can be gained over the results of these studies by further investigation until much longer and more complete stream-flow records have been obtained. These deficiencies and shortcomings are generally applicable to all stream-flow records in Oklahoma.

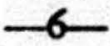




\section{Cost to Oklahoma of Lack of Water Facts}

What may the lack of water facts already have cost Oklahoma? in 1933 an engineering review by the Public Works Administration showed that the Denison Dam project involving "flood control and power development depended upon records of stream flow and precipitation which were anything but satisfactory." Although this project was finally approved by Congress in 1938 and was nearly completed in 1944, undoubtedly several years of benefits have been lost because of delays in construction occasioned by inadequacy of stream-flow data.

The storm of September 3-4, 1940, in eastern Pawnee and northern Creek counties, caused damages estimated in excess of half a million dollars, including $\$ 50,000$ at Cleveland Dam, and $\$ 50,000$ on Tulsa County highways. The $\$ 50,000$ loss at Cleveland Dam might have been prevented if data and information of maximum flows to be expected had been available for use in the design of the dam. Probably some of the damages suffered by the highways could have been averted if information on major floods had been available for use in culvert, bridge, and grade design.

The floods following the storm of April 3-4, 1934, caused the loss of 17 lives and damages estimated at about $\$ 3,000,000$ on the Washita River near Hammon. Undoubtedly the loss of some of these lives could have been prevented if records had been available indicating that the homes of those unfortunate people were hazardously placed and were liable to flooding and even destruction. Undoubtedly the damages to property would have been reduced if sufficient information had been available to have led to the design, within economic limits, of bridge openings to pass such a flood and the erection of dwellings at sites above the reach of the flood waters.

Could the disaster which occurred in Foss on May 4, 1903, with the reported loss of 7 lives have been, in part, prevented if it had been known that a flood of this magnitude might reasonably be expected within a short span of years?

Could the millions of dollars in damages suffered during the recent floods of May 1943 have been even partially lessened if full knowledge had been available of the stages and discharges reached during the great flood of 1833? It is confidently believed that such knowledge would have contributed to a more adequate design of many of the structures destroyed by the flood and influenced the placing above the flood line of much of the property damaged by inundation.

Lack of knowledge of influent seepage from surface water contaminated by oil field brines, resulted in the abandonment of Ponca City's ground-water supply at the cost of constructing a new surface-water 
supply. Similarly, the alluvium of the North Canadian River below Oklahoma City has been so impregnated with chlorides as to ruin it as a source of supply. If adequate knowledge of the behavior of the underflow in both these valleys had been available, Oklahoma would not have lost, at least for many years, the supplies of water obtained from two of the best ground-water reservoirs in the State.

Many similar incidents too numerous to mention have occurred. Many others will occur in the future unless the basic information aeeded for the design and planning of preventative measures are obtained and made available.

\section{Role of Water in Future Development of Oklahoma}

The expansion of any region will be controlled by the quantity and quality of its available water supplies, by reliable information concerning them, and by the ability to correct any objectionable features of such supplies by economical processes. The Oklahoma Geological Survey has stated that "Oklahoma's future hope lies in utilizing, through processing industries, the raw materials that are at hand" and that "water is by far the most important raw material in the entire list of natual resources." This means that adequate records of the quantity and quality of the surface and ground-water supplies must be available for a sufficiently long period of time and so distributed areally that there will be reasonably complete information on all phases of the quantity and quality of the supplies.

Survey of Water Resources of Oklahoma for Industrial Use

A survey of the water resources of Oklahoma for industrial use was begun on July 1, 1944, by the United States Geological Survey in cooperation with the Division of Water Resources of he Oklahoma Planning and Resources Board. In the course of this survey certain deficiencies in information about water in Oklahoma have become apparent. Each division of the United States Geological Survey engaged in the investigation has prepared recommendations with estimated costs for a program designed to give Oklahoma information in respect to the quantity and quality of its water supplies which will be adequate and sufficiently comprehensive to assist Oklahoma very materially in realizing fully its future possibilities in respect to industry.

\section{Federal-State Cooperative Investigations}

The United States Geological Survey is authorized to make general investigations of the Nation's water resources, and surveys and reports that are fundamental to the development and utilization activities of all agencies, to the adjudication and administration of rights, and to the determination of equities. For these purposes it measures the daily flow of surface streams; records fluctuations of lakes and reservoirs; investigates ground water to ascertain availability, depth, recharge, discharge, and storage; makes chemical analyses of both surface and ground waters with special reference to their fitness 
for use in agriculture and industry, and to their proper treatment for public and domestic water supplies, industrial processes, and steam-boiler use; and prepares statistical and interpretative reports--all with the view to furnishing reliable information that is essential as a basis for the full and best use of the water resources.

The information collected and published by the United States Geological Survey is used by Federal, State and municipal officials in connection with administration, operation, and utilization; by engineers and superintendents in connection with planning, designing, constructing and operating; by financiers in connection with the secu.ity of investments; by manufacturers and distributors of products used for the treatment of water or affected by the character of the water with which they are used; and by lawyers and by courts in connection with titles, equities, and damages. Its work is financed in part by direct Congressional appropriation, in part by cooperative funds provided by States and municipalities, and in part by funds furnished by other Federal agencies.

The United States Geological Survey's current program of water investigation in Oklahoma is conducted largely in cooperation with the State of Oklahoma and the Corps of Engineers. The scope of the current program, the deficiencies in this program, and proposals which contemplate expansions of the program along all lines of the Survey's activities related to water in an attempt to meet the diverse and growing Federal, State, and local needs, are set forth in detail under five headings, "Surface Water," "Ground Water," "Quality of Water," "Water Utilization," and "Topographic Mapping."

All or any portion of this program can be made available to Oklahoma at a cost of one-half of the estimated costs provided cooperative agreements with the United States Geological Survey are requested and entered into by State agencies. Under such agreements funds to defray the cost of the program would be provided in essentially equal amounts by the State of Oklahoma and the Federal Government. The present cooperative agreement with the United States Geological Survey is with the Division of Water Resources, Oklahoma Planning and Resources Board, in respect to surface waters, and with the Oklahoma Geological Survey in respect to ground water. An item for the biennium 1945-47 has been included in the budget of the Division of Water Resources, Oklahoma Planning and Resources Board, for the inauguration of an investigation of the quality of the surface waters of Oklahoma in cooperation with the United States Geological Survey. 


\section{SURFACE WATER}

Surface water is used chiefly in Oklahoma in connection with municipal and domestic water supplies, stock raising, power, industry and irrigation. As new industries are established to process the natural resources, increasing demands for surface-water supplies will result. To promote the progress of this expansion it is necessary to have available for use and consultation by potential industries adequate information on the quantity, availability and quality of surface water. As this can only be accomplished by observations over a long period of time, the present stream-gauging program must be continued.

In addition, an expansion of the present program must be started immediately to provide for the construction and operation of additional gauging stations in critical areas and on small tributary streams that are valuable as sources of small supplies. This enlarged program should proceed at the earliest possible date in order that all possible pertinent data and information may be accumulated and ready for use whenever needed so that there shall be no delay in the realization of the benefits from new projects.

\section{Present Program}

On December 31, 1944, the United States Geological Survey was operating in Okla.ioma 46 gauging stations, and in addition the Corps of Engineers was operating 42 gauging stations at which records of stage and discharge were being obtained. The United States Geological Survey, in addition to collecting, computing and publishing the records of discharge at its stations, also reviews and publishes the records of discharge obtained and computed by the Corps of Engineers. Thus all records of discharge collected by the two organizations are made available for the use of all interested parties through the Water Supply Papers of the United States Geological Survey.

Results of Program to Date

The stream-gauging program prior to 1936 was so sporadic that practically all of the stream-flow records collected during that period are fragmentary and discontinuous. In 1936 a planned and progressive program was belatedly started. At the close of 1944 , there is only one continuous stream flow record longer than 15 years, that on the Red River near Colbert which was established in October 1923. As of December 31, 1944, the State of Oklahoma is now well embarked upon a much too long deferred program of stream gauging which must be continuously improved and expanded if the fullest development and the wisest administration is to be made of its water.

Stream-Gauging Program of the Corps of Engineers

In connection with flood control and navigation studies and construction program carried on by the Corps of Engineers, operation of many of the existing gauging stations in the State is financed and largely conducted by that agency. When these programs are completed, some of the streamgauging work of the Corps of Engineers, although of general interest to the 
State, may no longer be needed by the Corps. In that situation, the State should plan to include in its cooperative program, those existing stations that might otherwise be discontinued because any break in the records at these stations would be a gieat loss.

Importance of Continuity, Length, and Areal Coverage of Records

Continuity and length are among the most important characteristics of a stream-flow record. Lack of these two important qualities has compelled the use of inaccurate and unsatisfactory estimates of stream flow, which have been made at great labor and cost from records of precipitation and available frag. mentary information. Precipitation records ir.dicate that, for the grcater part of the State, the 25-year period prior to 1918 was drier with the result that the runoff was probably less than in the subsequent 25 years. Records of stream flow on drainage areas of less than 100 square miles are practically nonexistent in Oklahoma. Long and continuous records on small areas are needed for use in lesign and operation of water supplies for small projects for irrigation and municipal use. There is no satisfactory substitute for actual stream-flow records. What loss this deficiency of basic water facts may eventually cause is entireiy conjectural but it might easily be far in excess of the entire cost of an adequate program of stream gauging. Undoubted', the completion of worth-while and economic developments in Oklahoma has already been delayed because of lack of adequate data, and the attendant benefits have been lost to Oklahoma.

Salaries and all costs of maintenance and operation are continuously rising and may rise still more after the close of the war. Equipment has deteriorated and must soon be replaced, and more discharge measurements are needed annually at many gauging stations. Oklahoma cannot afford to have its stream-gauging program regress. Consequently, provision must be made to provide additional funds for the continuation of the present program as well as for a normal healthy growth and expansion.

Need for Information for Redu tion of Losses in Storage

The flow of the streams in Oklahoma is so erratic throughout the seasons and years that storage must be generally provided to catch the flood runoff for later use as needed. The deposition of silt in and the evaporation of water from these storage reservoirs (whether they are stock tanks or large reservoirs devoted to uses of irrigation, power, industries, municipal water supply, flood control, or other purposes) take a tremendous toll each year from reservoir capacities and from the stored water. They may actually render shallow reservoirs practically valueless. Studies should be undertaken to determine some method for the reliable evaluation of evaporation losses, perhaps such as the relation between the evaporation from a standard Weather Bureau evaporation pan and actual evaporation from water surfaces. Information so obtained would result in making better provisions for minimizing the losses and for so 
allowing for such losses that reliable water supplies would be assured even under unfavorable conditions.

Value and Use of Information on Maximum Stages

The elevation of maximum stages reached by noteworthy floods should be obtained and made available in sufficient detail to lead to the location of buildings and developments above the probable reach of flood waters. Knowledge of flood stages of the past can be a means of averting incalculable losses if used as a basis for placing property and projects safely outside the destructive grasp of flood waters. This information, when available, is now extensively used by the Corps of Engineers and other organizations in evaluation of benefits accruing from flood control.

\section{Losses of Water From Channels}

In the reaches of the Canadian River between Taloga and Newcastle, of the North Canadian River between Woodward and El Reno, and of other streams in western Oklahoma, available records indicate that much water is lost from the channels. Losses of valuable water from natural and artificial channels under similar conditions might be averted as a result of an accumulation of knowledge of the cause of the losses.

Records of Streams Near State Boundary to Safeguard Rights of Oklahoma

Much surface water now available to Oklahoma originates in other States and the availability and quality of the supply may be adversely influenced by changes in those States in the uses of water and the exercise of rights over which Oklahoma has no control. Changes in use-domestic, agricultural, commercial, and industrial-accompanying further development in upstream States may decrease materially the stpplies of water received from such States. Polluting uses may so change the quality of water as to render it unfit not only for man's uses but also as a habitat for fish. Therefore, records of the quantities and quality of water in the principal streams entering and leaving the State should be included in any program in order to obtain information of trends of changes in the water received from outside sources and of changes which Oklahoma may be making in water as it flows across the State. Such information will be especially useful in safeguarding the rights of Oklahoma in interstate streams.

\section{Comprehensive Program}

A summary of the estimates of annual costs of continuing the present stream-gauging program and of so enlarging the program as to remedy the most apparent deficiencies in surface water facts in Oklahoma is presented in Table 1. Existing gauging stations are listed in Table 2 and proposed gquging stations in Table 3 . The locations of existing and proposed stream-gauging stations are shown on the accompanying map, Figure 1. 


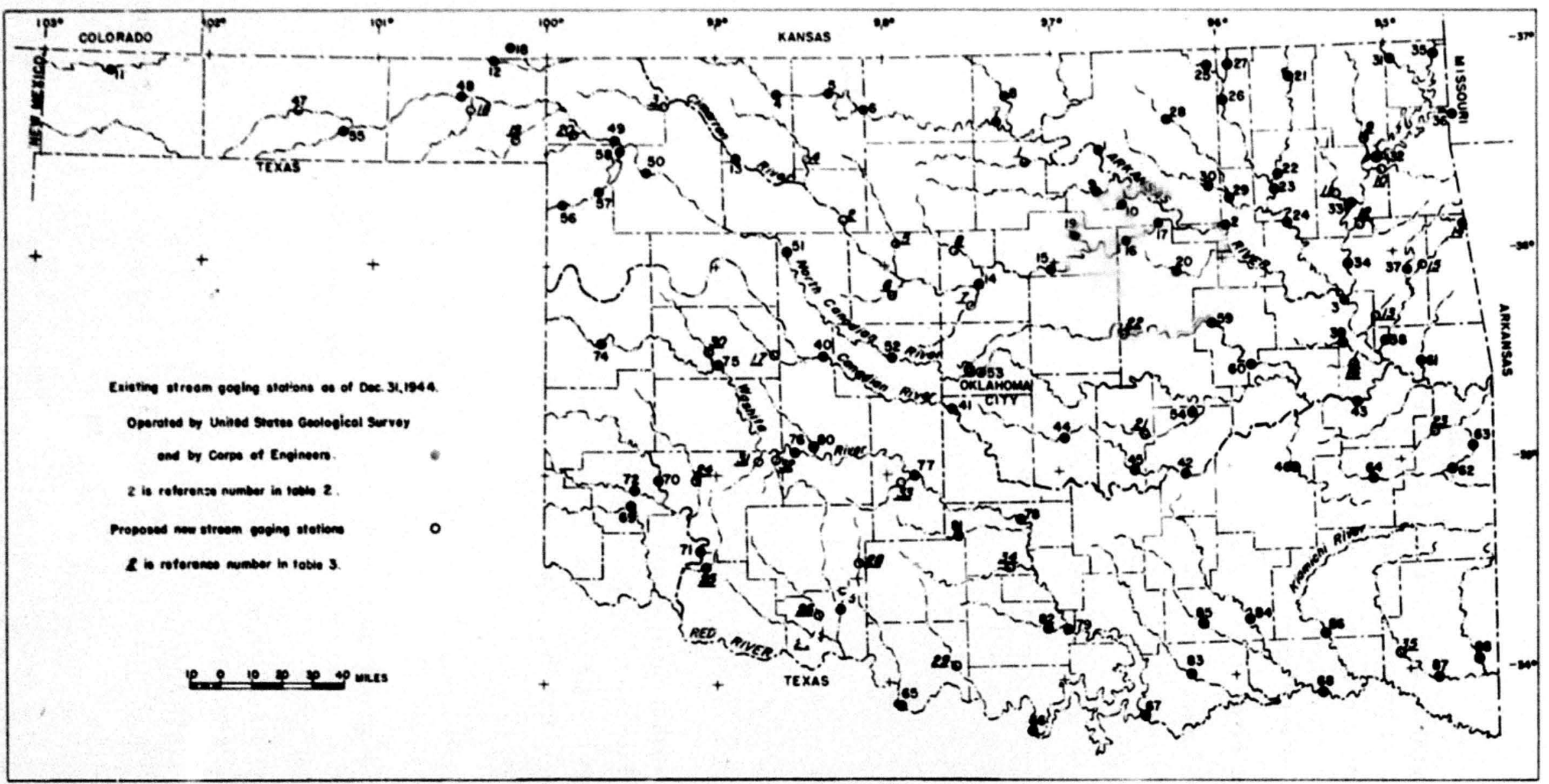

Figur L.- Mop of Othathomo showing locotion of existing and proposed new stream gaging stotions. 


$$
\text { Ta } 1
$$

Estimated Annual Costs of a Compichensive "Surface Water" Program Exclusive of program of Corps of Engineers

Continued operation of 46 gauging stations, not including partial cost of operation of $\mathbf{2 0}$ gauging stations furnished by Corps of Engineers

Annual cost

(See Figure 1 for location and Table 2 for list)

Establishment over a period of $S$ years, with operation after construction, of 35 new gauging stations at critical points on critical areas:

(See Figure 1 for location and Table 3 for list)

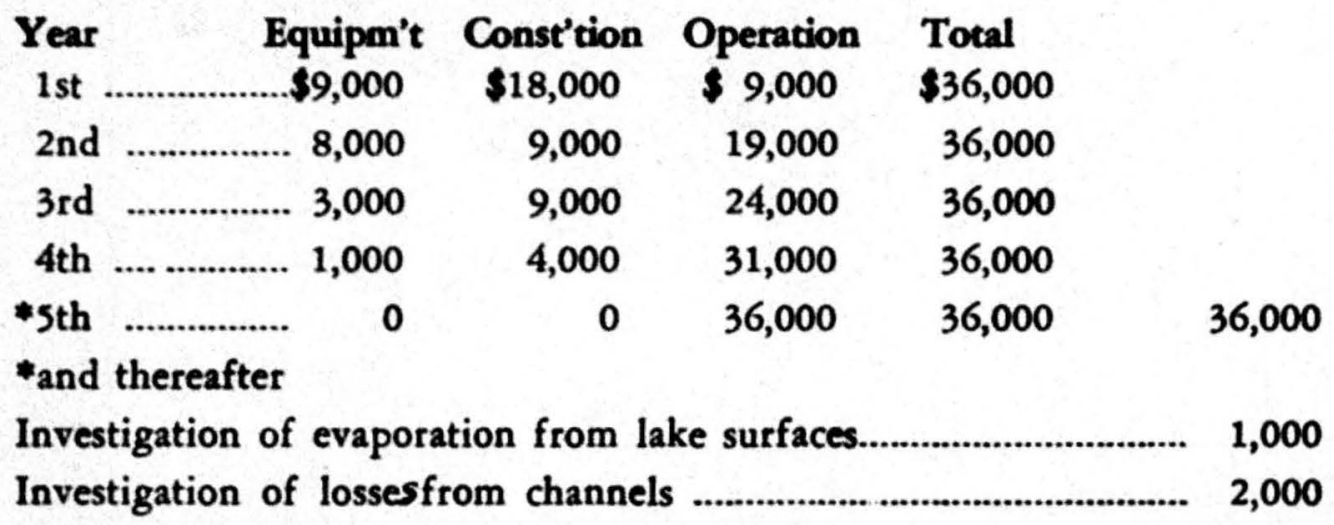

Total annual cost of partial program $\$ 75,000$ Present Program of Corps of Engineers

Full cost of operation of $\mathbf{4 2}$ gauging stations (See Figure 1 for locations) and partial cost of operation of 20 gauging stations 53,000

Total annual cost of full program $\$ 128,000$

Estimated annual costs to the State of Oklahoma under a cooperative agreement and program with the United States Geological Survey.

PARTIAL PROGRAM:

Exclusive of program of Corps of Engineers.......................\$37,500

\section{FULL PROGRAM:}

Including that now supported by Corps of Engineers. $\$ 64,000$ 
Ref. No.

\section{Table 2-Existing Stream-Gauging Stations in Oklahoma}

Fig. 1 ARKANSAS RIVER BASIN

1. Arkansas River at Ralston

*2. Arkansas River at Tulsa

3. Arkansas River near Muskogee

*4. Salt Fork Arkansas River near Alva

*5. Salt Fork Arkanșas River near Cherokee

*6. Salt Fork Arkansas River near Jet

7. Salt Fork Arkansas River at Tonkawa

8. Chikaskia River near Blackwell

*9. Black Bear Creek near Pawnee

10. Ranch Creek near Cleveland

11. Cimarron River near Boise Car's

12. Cimarron River near Mocane

*13. Cimarron River near Waynoka

14. Cimarron River near Guthrie

*15. Cimarron River at Perkins

16. Cimarron River at Oilton

*17. Cimarron River at Mannford

18. Crooked Creek near Nye, Kansas

19. Council Creek near Stillwater

*20. Polecat Creek near Heyburn

*21. Verdigris River near Lenapah

*22. Verdigris River near Sageeyah

23. Verdigris River near Claremore

*24. Verdigris River near Inola

*25. Caney River near Hulah

*26. Caney River near Bartlesville

*27. Little Caney River near Copan

*28. Bird Creek at Pawhuska

29. Bird Creek near Sperry

*30. Hominy Creek near Skiatook

31. Neosho River near Commerce

32. Neosho River near Langley

33. Neosho River near Choteau

34. Neosho River near Wagoner

35. Spring River near Quapaw

36. Elk River near Tiff City, Mo.

37. Illinois River near Tahlequah

38. Illinois River near Gore

*39. Dirty Creek near Warner

*40. Canadian River near Bridgeport

41. Canadian River near Newcastle

442. Canadian River at Calvin

43. Canadian River near Whitefield

*44. Little River near Tecumseh

45. Little River near Sasakwa

46. Gaines Creek near Krebs 
TABLE 2-(continued)

Ref. No.

Fig. 1 ARKANSAS RIVER BASIN

47. North Canadian River near Guymon

48. North Canadian River near Beaver

-49. North Canadian River near Fort Supply

-s0. North Canadian River at Woodward

*51. North Canadian River at Canton

52. North Canadian River near El Reno

53. North Canadian River near Oklahoma City

54. North Canadian River near Wetumka

*55. Coldwater Creek near Hardesty

-56. Wolf Creek near Shattuck

*57. Wolf Creek near Fargo

458. Wolf Creek near Fort Supply

459. Deep Fork near Beggs

60. Deep Fork near Devar

61. Sallisaw Creek near Sallisaw

62. Poteau River near $W$ ister

63. Poteau River at Poteau

64. Fourche Maline near Red Oak

RED RIVER BASIN

65. Red River near Terral

*66. Red River near Gainesville, Texas

67. Red River near Colbert

*68. Red River at Arthur City, Tex.

69. Salt Ford Red River at Mangum

70. North Fork Red River near Carter

71. North Fork Red River near Headrick

72. Elm Fork North Fork Red River near Mangum

73. Cache Creek near Walters

*74. Washita River near Cheyenne

75. Washita River near Clinton

76. Washita River at Carnegie

77. Washita River near Tabler

78. Washita River near Pauls Valley

79. Washita River near Durwood

80. Pond Creek near Fort Cobb

*81. Rush Creek near Purdy

*82. Caddo Creek near Ardmore

*83. Blue River near Blue

* 84. Muddy Boggy Creek near Farris

* 85. Clear Boggy Creek near Caney

*86. Kiamichi River near Belzoni

*87. Little River near Idabel

*88. Mountain Fork River near Eagletowa

-Operated by Corps of Engineers 


\section{Table 3-Proposed Additional Stream-Gauging Stations in Oklahoma}

Ref. No.

Fig. 1 ARKANSAS RIVER BASN

1. Red Rock Creek, Red Rock

2. Cimarron River, Ames

3. Buffalo Creek, Salt Springs

4. Eagle Chief Creek, Aline

5. Turkey Creek, Hennessey

6. Kingfisher Creek, Kingfisher

7. Cottonwood Creek, Sewand

8. Ephraim Creek, Lovell

9. Big Cabin Creek, Ketchum

10. Spavinaw Creek, Spavinaw

11. Pryor Creek, Pryor

12. Spring Creek, Murphy

13. Greenleaf Creek, Braggs

14. Illinois River, Watts

15. Barren Fork, Eldon

16. Georges Fork, Warner

17. Deer Creek, Hydro

18. Clear Creek, Beaver

19. Kiowa Creek, Logan

20. Clear Creek, May

21. Wewoka Creek, Wewoka

22. Deep Fork, Stroud

23. Brazil Creek, Milton

RED RIVER BASIN

24. Elk River, Hobart

25. Otter Creek, Headrick

26. West Cache Creek, Walters

27. Deep Red Run, Randlett

28. Beaver Creek, Nellie

29. Mud Creek, Atlee

30. Barnitz Creek, Arapaho

31. Rainy Mountain Creek, Mountain View

32. Saddle Mountain Creek, Carnegie

33. Littie Washita River, Ninnekah

34. Wildhorse Creek, Hennepin

35. Little River, Wright City 


\section{GROUND WATER}

Ground water is utilized in s.ll parts of Oklahoma for municipal, agricultural, industrial and stock-raisir.g purposes. Ground water is available over most of the State and it is the only source of water in most parts of western Oklahoma. Throughout the state, practically all of the rural population depend on the ground-water reservoirs to supply their water needs. However, although areally extensive, the quantity of ground water available for various uses is definitely limited, and the quality varies considerably from aquifer to aquifer and within the aquifer tself. In the postwar expansion, an orderly and proper development of its 'vater resources must be undertaken to assure Oklahoma of its maximum development in the future growth of the Nation. As a part of this undertaking, the devilopment of the ground-water resources is predicated on a thorough knowledge of the occurrence and behavior of water in the great underground reservoirs underlying the State.

\section{Review of Program to Date}

Oklahoma is deficient in knowledge of its ground waters in most areas of the State, although the need for such knowledge was recognized even before statehood. In 1905 Prof. C. N. Gould was the professor of geology in the University of Oklahoma, and was associated with the United States Geological Survey; later he established and directed the Oklahoma Geological Survey. $\Lambda$ report ${ }^{1}$ prepared by him on the water resources of Oklahoma Territory was published in 1905. This general report based on a reconnaissance survey of information then existing is still useful. However, most of the deeper aquifers were not tapped until much later, when improvements in drilling equipment made deeper wells possible and better pumps made high-lifts practicable.

In the period 1905 to 1937 , several short reports dealing with ground water in scattered localities were published or mention was made of ground water in reports dealing primarily with other topics. ${ }^{2}$

1. Gould, C. N., Geology and Water Resources of Oklahoma: U. S. Geological Survey W.S.P. 148. 1905.

2. Seibenthal, C. E., Mineral Resources of Northeastern Oklahoma: U. S. Geological Survey Bull 340C. Pp. 225-228, 1908. Phillips. Alvord and Bililingsley, Report to the Mayor and Board of Commissioners of Oklahoma
City on an improved water supply for the city: PP. 98-133. 1913.

Siebenthal. C. E., Origin of the Zine and Lead Deposits of the Joplin Region: U. S. Geological Survey Buil. 606, pp. 33-37, 99-100, 105, 137-140: 1914. Schwenneson, A. T. Ground Water for Irrigation in the Vicinity of Enid, Oklahoma: U. S. Geo-

Schwennesen, A. T. Ground Water for Irrigation in the Vicinity of the North Fork of the Canadian River near Oklahoma City, Oklahoma: U. S. Geological Survey W.S.P. 345d, 1914.

Thompson, D. G. Ground Water for Irrigation near Gage, Ellis County, Oklahoma: U. S. Geological Survey w.S.P. $500 \mathrm{~b}, 1922$.

Renick, B. C.. Additional Ground-Water Supplies for the City of Enid, Oklahoma: U. S. Geological Survey W.S.P. \$206, 1925. 
In 1942 a report (Publication No. $52 \sim$ the Oklahoma $A$ gricultural and Mechanical College) by Otto M. Smith, Robert H. Dott and R. C. Warkentin was published, entitled The Chemical Analyses of the Waters of Oklahoma. This report includes a discussion of the geology of the ground water in Oklahoma by Mr. Dott.

In 1937 the present cooperation between the Oklahoma Geological Survey and the United States Geological Survey was initiated, and intensive investigations of the ground-water resources of the Oklahoma Panhandle were started. Figure 2 shows the location of the areas investigated under this cooperative program. The work in Texas and Cimarron Counties has been completed and reports on these two Panhandle courties by S. L. Schoff have been published as bulletins ${ }^{3}$ of the Oklahoma Geological Survey. Field work in Beaver County is practically completed but the writing of the report is being postponed until Mr. Schoff returns from military service as a ground-water expert. In the meantime, his notes and a short summary of ground-water conditions in the county are on file in the of fice of the United States Geological Survey at Norman and are available for use in answering inquiries concerning groundwater problems in Beaver County.

Field work on similar investigations of the ground-water resources of alluvial formations underlying the North Canadian River Valley in Oklahoma and Canadian Counties, of the Garber sandstone and Wellington formation of Permian age in Oklahoma and Cleveland Counties, and of the Ordovician rocks of northeastern Oklahoma have been completed or are in progress and the information obtained is available at Norman. In addition, fragmentary information concerning localities in different parts of the State, obtained in connection with the answering of inquiries on local ground-water problems, is also on file at Norman.

Thus a very meager start has been made in obtaining the vast amount of ground-water data necessary as a basis for understanding and developing the potentialities of this important natural resource. Remaining to be investigated are the other main water-bearing formations of the State-the Nelagoney and Vamoosa formations of east-central Oklahoma, the Whitehorse sandstone of west-central Oklahoma, the Trinity sand of southeastern Oklahoma, the Clear Fork and Wichita formations which cover most of the southwestern section, the terrace deposits scattered over the western half of the State, and the alluvium of the major river valleys. In addition, there are many minor aquifers which will not yield large amounts of water but which are nevertheless important in the areas which they underlie. Among such are the Boone limestone

1. Schoff, S. L., Geology and Ground Water Resources of Texas County, Oklahoma : Oklahoma Geological Survey Bull. 59.1939.

Schoff, S. L., Geology and Ground Water Resources of Cimarron County. Oklahoma: Oklahoma Ceological Survey Bull. 64, 1943. 


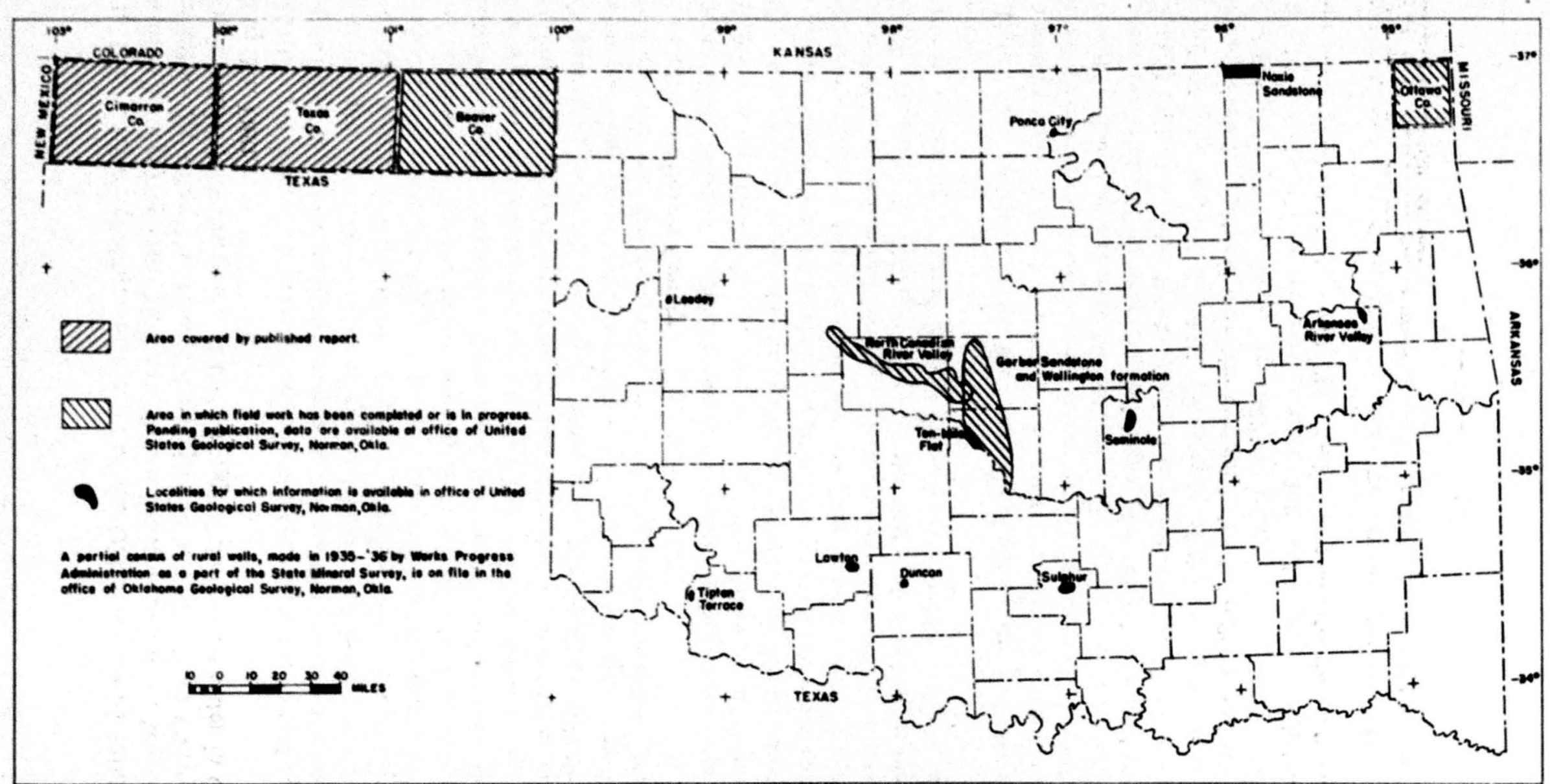

Figure 2- Mop of Otlohome showing orees in which cooperotive ground woter investigotions hove been mode since 1937 or ore in progress. 
of northeastern Oklahoma; the Chelsea sandstone lentil of the Cherokee formation near Claremore; the Seminole conglomerate near Tulsa; the Simpson group and the Pontotoc group of the Arbuckle Mountain region; formations of the Arbuckle groups on the flanks of the Wichita and Arbuckle Mountains: and the alluvium of the minor streams.

\section{A Comprehensive Program}

A comprehensive program to obtain the lacking information should consist of intensive studies and reports on the occurrence and behavior of ground water in the major aquifers enumerated above, followed by similar studies, county by county, throughout the State. The minor aquifers would be interpreted in these county reports and it might prove feasible to issue the groundwater reports in the series of Oklahoma Geological Survey Bulletins on "Geology and Mineral Resources" of individual counties. Comprehensive groundwater data should be included in the proposed report on "Economic Geology of Oklahoma."

A thorough investigation of the water of an aquifer or of the groundwater iesources of a specific area consists of several phases. The geology of the area must be studied thoroughly - the geology of the outcrop, the structure and the stratigraphy of the aquifer, and the composition of the rock itself, in relation to its ability to transmit water. This calls for geologic mapping in the field, laboratory analyses of water-bearing materials including sieve tests to determine the percentage of grain sizes, collecting and correlating well logs, and working out geologic problems related to the particular aquifers in the area: An inventory of existing wells must be made and estimates must be made of the total present and past pumpage from each aquifer. An observation well program must be set up to determine the shape and fluctuations of the water table or piezometric surface. This should consist of a series of wells whose water levels are registered by automatic water stage recorders or are measured periodically. Samples of water from various wells in the area must be collected and analyzed to determine the quality of water available. The quality may vary both laterally and with depth. Field pumping tests and laboratory permeability tests should be made to determine the ability of the aquifer to transmit water. From these tests the proper pumpage rates and the proper well-spacing can be computed, and the overall safe yield of the aquifer can be determined. Test drilling with some electric logging and geophysical exploration will be needed to determine the occurrence of and the depth to the different aquifers, their relation to the intake areas, and the presence of faults or other barriers to the flow of the ground water. A report must be prepared and published.

A statewide observation well program should be established as soon as possible to start obtaining long-term records of fluctuations in the water table 
and piezometric surface of the various ground-water reservoirs. The value of long-term records in analyzing the potentialities of a ground-water supply has been demonstrated many times. The longest continuous record available is that in the Stillwater Creek Basin in Payne County, established in 1934. The Panhandle program was started in 1937, the North Canadian River Valley program in 1941, the Canadian County program in 1942, and the Cleveland and Oklahoma County program in 1943. The wells in these programs are measured at varying intervals by the Norman office staff of the United States Geological Survey or by local observers. The accompanying map, Fig. 3, shows the location of the present observation wells and indicates the large portion of the State that is not covered by the program. In order to cover the State adequately, about 30 key obseryation wells are needed in addition to the present wells. Several of these wells siould be equipped with water-stage recorders to give continuous records; in others, weekly measurements will be sufficient. In addition, a considerable number of observation wells will be needed in the heavily pumped areas. Abandoned wells can often be utilized as observation wells, but eventually the program should be based to a considerable extent on wells drilled specifically for the program.

\section{Pollution and Contamination of Ground Water}

Pollution of ground water from oil field brines and other industrial wastes and contamination from natural causes have caused problems in various areas in the State for a long time. With increased industrialization in Oklahoma, it is reasonable to expect that these problems will increase. The proper solution of present problems and prevention of future ones, necessitates a thorough knowledge of the occurrence and behavior of the ground water. In some cases, intelligent application of the physical laws governing the movement of the ground water will be sufficient to eliminate the possible causes of such pollution and contamination, but in others special investigations will have to be made. These special investigations may call for considerable field work, a continuous sampling program to determine the progression of the polluted water, or various other methods of determining the source and movement of th: polluted water. For example, the salt water from an oil well may progress over the surface, or it may be coming from an abandoned oil well because of repressuring operations or through a porous subsurface stratum. A number of samples collected in the area might easilyl determine the origin in the first case mentioned, but the origin in the second or third case would be more difficult to determine. 


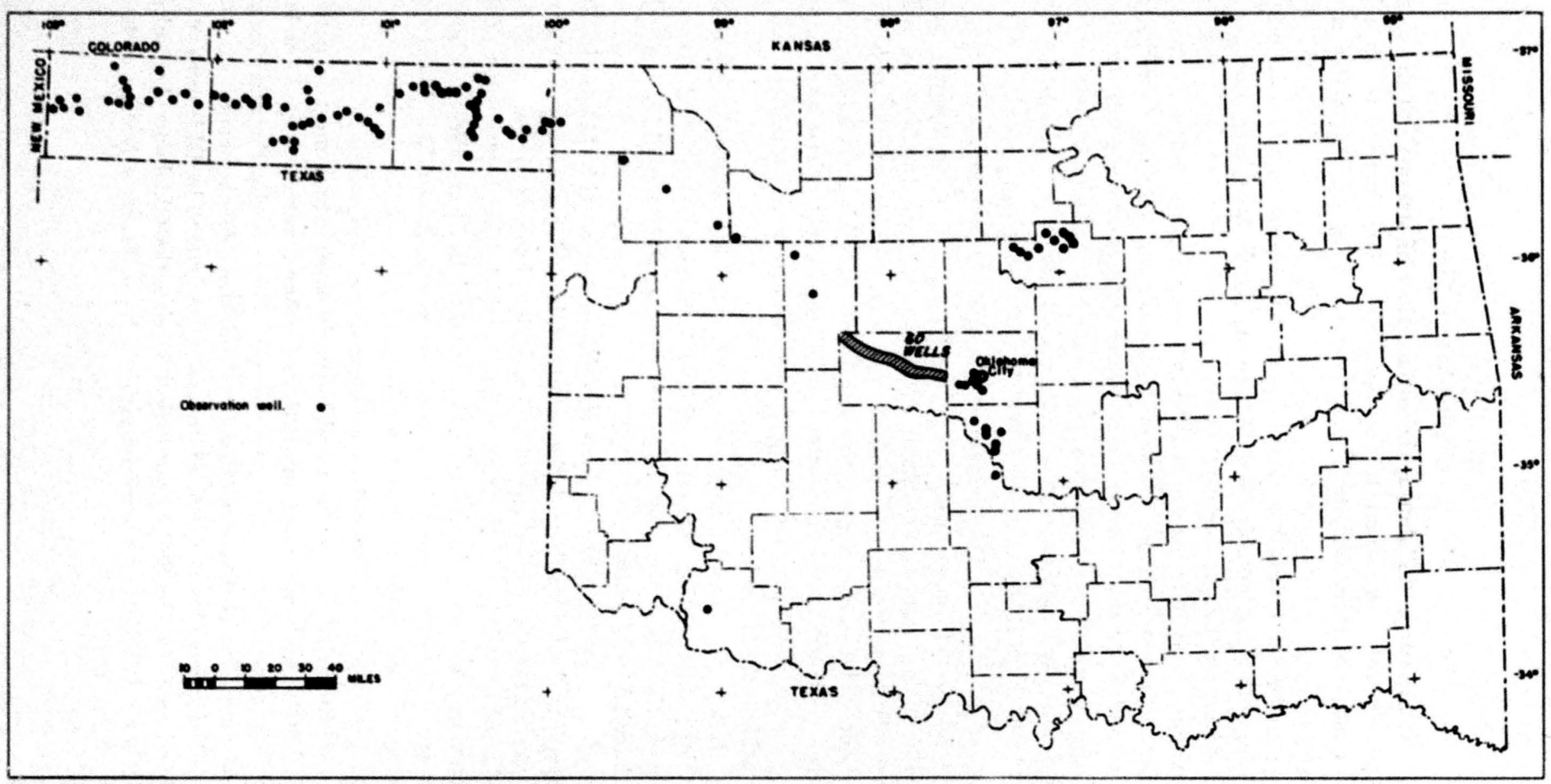

Figure 3-Mop of Otlohomo showing locotion of existing observation wolls. 
in several areas, not only in the semi-arid western part of the State but in the relatively humid eastern part, where lack of rainfall in the dry summer months had forced the marketing of vegetables and fruits at times when prices were extremely low. Development of irrigation by ground water in Oklahoma will depend on adequate knowledge of the occurrence, quantity and quality of the ground water.

\section{SPECIAL PROJECTS}

In analyzing ground-water problems, losses by transpiration of plants and evaporation are important. Not enough is known about these losses and further work is desirable.

Similarly, channel losses along stretches of the North Canadian and Canadian Rivers constitute a problem involving both surface water and ground water. Its solution will depend on knowledge of discharge of streams, the underflow, and of the geology of the valley itself.

\section{Total Annual Costs and Annual Cost to Oklahoma}

An estimate of the annual cost of a continuing comprehensive groundwater program embodying all the factors discussed herein is:

Continuation of present program with expansion to other aquifers, program of observation wells, and special projects $\$ 40.000$

Chemical analysis of ground water ....................................... 2,000

Test drilling, logging of wells, and geophysical exploration.... 30,000

Total $\$ 72,000$

By expanding the present cooperative set-up between the Oklahoma Geological Survey and the United States Geological Survey, the Federal Government will essentially match State funds, dollar for dollar, so that the cost to the State of Oklahoma of the comprehensive ground-water program described herein would be about $\$ 36,000$ per annum. 


\section{QUALTY OF WATER}

Records of the chemical character of surface and ground waters throughout Oklahoma are needed because the extent of industrial development in Oklahoma will be limited in large measure by the adequacy of water supplies of suitable chemical quality.

The quantities of dissolved and suspended matter affect the usefulness of water in almost every line of manufacturing. Some industries have more rigid requirements for the chemical quality of water than do other industries. Those requirements may be met by natural water; or treatment of the local water supply may be required. A water supply of good quality cannot always be obtained at the site considered for a plant.

The analyses made by the United States Geological Survey are planned to show the quantities of suspended and dissolved material that determine the fitness of the water for industrial or agricultural use, and for those domestic uses that are affected by these constituents, without any reference to sanitary problems. A quality-of-water investigation is, however, much more than a mere making of routine analyses by established standard methods. Sound planning of the sampling program is necessary to insure complete continuing records on all phases of the investigation. Careful scrutiny of the analyses is needed to determine their accuracy and in some instances to decide upon the validity of the sampling. Careful compilation and correlation of the analytical data is required for publication.

The chemical quality of the surface and ground waters throughout Oklahoma has been considered only in general aspects in studies already completed. The quality of the water in streams differs widely throughout Oklahoma, due not only to natural conditions, but also to pollution by oil field brines, sewage, mine wastes, and industrial effluents. Pollution may, in extreme cases, make the water unfit for any purpose, not only for all ordinary uses, but also as a habitat for fish life. Highly mineralized waters not only affect the specific locality where the pollution occurs, but they may also adversely affect the quality of the water for downstream users even though miles away. The ground waters in the State have been, and will continue to be used for industrial and municipal supplies as well as for irrigation. The ground waters may differ widely in chemical character. On the following pages is outlined a comprehensive program for the study of the chemical compositions of the waters throughout Oklahoma. 


\section{Quality of Surface Waters}

There are few data on the quality of the surface waters in Oklahoma. Some information on the chemical composition of waters in the Red River and Canadian River basins has been obtained by the United States Bureau of Reclamation. ${ }^{3}$ At most points, however, this information consists of analyses of a few spot samples scattered throughout a year. Analyses of surface waters at a few points throughout the State have been compiled by Smith. ${ }^{4}$ The United States Geological Survey is currently making analyses of spot samples from numerous points and of composites of samples collected daily at six stations on streams in Oklahoma, but this study terminates December 31, 1944. While these analyses give a rough idea of the quality of the water in some streams, the data are too fragmentary to be of general significance. There has been no systematic continuing program for obtaining quality of water data on surface waters in Oklahoma.

The analytical data show that most surface streams in Oklahoma vary widely in chemical comp'ssition. There are few streams of moderate size in the State which from their headwaters to their lower reaches are fairly uniform in concentration at any time or constant from time to time. A river water might have at different times as much as fifty per cent less than the average or more than one hundred per cent above the average amount of dissolved matter. Full consideration must be given to these variations in compotions when storage is not provided, especially for industries using water every day in the year.

Some surface water supplies are very poor in quality at many times of the year, but the available records do not in any way show the variations in chemical composition of the river water throughout the year. It should be stressed that samples collected every day in the year furnish the only sound basis for evaluating the relative effects of highly mineralized low flow and the much better water available during and following floods.

A knowledge of the quality of surface water that may be expected throughout the year and from year to year depends on a sampling program covering years. An analysis of a spot sample from a stream may be misleading and should not be taken as a basis for the choice of a source of an industrial water supply. For some waters that carry large amounts of soluble salts, or are affected by mineral matter from extraneous sources, such as oil wells, return water from irrigation or industrial wastes, as much as ten years of study are required. Consequently, there is usually insufficient time to obtain reliable quality-of-water information if investigations are not begur before the need arises.

3. Unpublished data. Files, Burean of Reclamation, Oklahoma City, Okla.

4. The Chemical Analysis of the Water of Oklahoma: Oklahoma A. \& M. College. Er.g. Pub. No. 52 , Smith, O. M., Vol. 12, No. 1, 1942. 
Daily samples with analyses of ten-day composites, in general yield the be followed and an accurate prediction can be given as to the industrial value information desired. With such a sampling program, the daily variations may of impounded waters that would be available for the project. As the concentration of the mineral matter in solution varies with the amount of water flowing in the stream, it is necessary that adequate stream-flow records be obtained at all sampling stations. The quality of surface water is generally improved following heavy rains when large volumes of water are carried in streams. Because of these flood flows the water in most large lakes is usually of better quality than would be found in the low flow of tributary streams. Thus the amount of rainfall and of surface runoff, which often vary widely from year to year, will materially affect the average chemical composition of the water in a stream. A correlation of the chemical quality of the water with the rates of discharge for the years of study, applied to the discharges of other years, makes it possible to indicate whether the period studied was representative of average conditions and also something of what the extreme and average compositions might be. Generally, to obtain a reliable figure for this average concentration, records of daily samples for many years may be necessary.

For a comprehensive investigation of the industrial quality of the surface waters in Oklahoma, it is proposed to make chemical analyses of composites of daily samples from about 12 points each year at stream-gauging stations where records of discharge are available. The stations would be selected and operated on the main stems of major rivers throughout the State to determine the fitness of water for industrial use and on as many tributary daily sampling points are contemplated for the initial study:

$\begin{array}{ll} & \text { Group I } \\ \text { Arkansas River at Arkansas City, Kaos. } & \text { Washita River near Durwood } \\ \text { Arkansas River at Tulsa } & \text { Canadian River near Whitefield } \\ \text { Arkansas River at Van Buren, Ark. } & \text { Poteau River at Poteau } \\ \text { Verdigris River near Sageegah } & \text { Deep Fork near Dewar } \\ \text { Neesho (Grand) River near Wagoner } & \text { Washita River near Clinton } \\ \text { Illinois River near Gore } & \text { North Canadian River at Canton }\end{array}$

Sampling at these points would be continued until adequate analytical streams as may be necessary to determine the proportion of total salt load contributed by each tributary in specific reaches of the river. The following records are obtained, probably for several years. Then other sampling points would be selected on the basis of existing data and current needs for qualityof-water data on other streams, or at other points on the same stream.

The following list of supplementary sampling stations, also located at stream-gauging stations, would be desirable in a well-rounded study of the chemical character of the surface waters throughout the State: 
Spring River near Quapaw

Little River near Idabel

Neosho River near Commerce

Kiamichi River near Belzoni

Canadian River near Bridgeport

Canadian River at Calvin

North Canadian River near Wetumka

\section{Group II}

North Fork Red River near Headrick

Prairie Dog Town Fork Red River near Estelline, Texas

Cimarron River àt Mannford

Cimarron River near Waynoka

Cimarron River near Guthrie

Salt Fork Arkansas River at Tonkawa

Analyses would be made of samples collected less frequently at other points on streams in the State. Adequate records of water temperatures would be obtained at all sampling stations. The estimated cost of such a program, including the operation of sampling stations in Groups I and II for each year, analyzing the samples, and preparing the analytical data for publication would be about $\$ 22,000$ per annum, $\$ 12,000$ for Group I and $\$ 10,000$ for Group II.

In addition to providing information on the possibilities of industrial use of the waters, the extent and character of stream pollution by highly mineralized wat rs from natural salt springs and streams, oil fields, industrial wastes, and sewage can be evaluated under such a program. A continuing sampling program is important from a pollution abatement standpoint. Seasonal and annual loads of dissolved salts can be calculated and the areas of major salt contribution to streams could be determined. The analyses would provide a very valuable store of information for the future development of water supplies for municipalities and for irrigation.

Three sampling stations vere established September 1, 1944, in connection with a preliminary survey of the water available for industrial uses in Oklahoma. Funds are allotted to maintain these stations through December 31, 1944. As the records being obtained at these stations are necessary for commencing a sound quality-of-water program, it would be desirable to preserve the continuity of these records. It is estimated that an additional $\$ 1,000$ contribution by the State together with an equal allotment by the United States Geological Survey would be ample to carry the work to the end of the current fiscal year pending the initiation of a comprehensive quality-of-water program.

\section{Sediment Loads}

The comprehensive systematic measurement of silt carried by streams in Oklahoma is an integral part of a well rounded study of industrial utility of the water supplies in the State. Considerable information on the sediment loads has been gathered by the Corps of Engineers ${ }^{5}$ on streams throughout the State in connection with studies on silting of river beds, influence of the navigability of the streams, and the effect of large quantities of silt on reservoir capacities. However, silt samples were generally taken only occasionally so that some of the data are inadequate, particularly during flood flows when tremendous quantities of sediment are transported. It is impossible to determine sediment loads on the basis of only a few samples a year.

5. Unpublished Records. U. S. Engineers Office, Tulsa, Okla., Denison, Texas. 
Suspended matter in appreciable amounts affects the usefulness of the water for industrial as well as domestic purposes. It is an important factor in the design and operation of purification systems. Consideration must be given to quantities of suspended matter in streams in determining whether an industry will find it possible to use the source for its water supply. Large quantities of silt carried by many streams in Oklahoma create problems in the maintenance of irrigation canals and structures, and also fill reservoir space needed for conservation and flood control. Consequently, additional quantitative data of sediment loads in many streams in Oklahoma will be essential for the sound planning of the development of industrial water supplies. The collection of samples from at least six key stream-flow gauging stations would be desirable in a comprehensive program for the measurement of sediment loads in Oklahoma. Each sampling station should be continued for as long a period as necessary for adequate records of the quantities of suspended matter carried in the stream at that point. Data on the sediment loads would be desirable at many if not all of the chemical observation stations. The needs and demands for silt data at prospective reservoir sites now not under immediate consideration will influence the selection of the sampling points when the investigation is initiated The samples would be collected from one to three times daily at the stations, depending on the characteristics of the stream and the discharge at the time of sampling. Analyses of each sample for total sediment content would be made and the chemical analyses for a representative number of samples would also be made. The estimated cost of operating the sediment stations, purchase of equipment, analyses of samples, and preparing the data for publication would be about $\$ 15,000$ per year.

\section{Quality of Ground Water}

Ground waters of the State have been and will continue to be used extensively for industrial purposes, domestic and public water supplies, and for irrigation and stock purposes. Composition of ground waters bears a relation to the rock formations in which they occur, and knowledge of their composition may be of value in tracing sources of underground waters.

Knowledge of the chemical composition of the waters will be an interra part of any general investigation of ground-water conditions in Oklahoma. The sampling program should be closely co-ordinated with the studies of the geology and ground-water resources contemplated by the United States Geological Survey. The extent and cost of a study of the quality of underground waters would be proportional to and contingent upon the funds provided for the studies of the ground-water resources of Cklahoma.

Some data have been compiled on the chemical composition of underground waters in Oklahoma, $3,4,6$ though the analyses cover only small areas 3. Op. cit.

4. Unpublished data. Files, U. S. Geological Survey, Norman, Oklahoma. 
scattered throughout the State. Water well surveys are needed in many areas in Oklahoma where important supplies of ground water are known to exist. Some analyses are available on the waters from the main formations which furnish a general picture of the quality of potable ground waters in Oklahoma. However, in more than half the counties, quality-of-water information is decidedly inadequate, five counties not having even a single analysis of well water

For a comprehensive study of the chemical character of ground water in Oklahoma, it would be desirable to make complete analyses of samples from as many wells as necessary for fully representative coverage. Ground waters of inferior quality should be explored by intensive and extensive sampling to ascertain the chemical character of these waters for whatever purpose that they might be used. In all intensively developed areas, it would be desirable to select key wells from which samples would be taken periodically for chemical analysis in order to follow any changes in chemical character of the water as the result of excessive withdrawals from the underground reservoirs. Appreciable quantities of fluoride in many public and domestic water supplies have been reported by the Oklahoma State Health Department. ${ }^{4}$ Excessive quantities of fluoride make the water undesirable and even unsatisfactory for some domestic uses, hence it would appear desirable to make further investigations of the occurrence of this constituent in well waters throughout Oklahoma. It has been found that boron in small quantities in irrigation waters may injure crops unless precautionary measures are taken. Boron in appreciable quantities has been observed in many ground waters in Oklahoma and such supplies should receive critical examination for this constituent before being developed for irrigation.

The damage to ground-water supplies by contamination by oil field brines, refinery wastes, mine seepage, and other wastes should receive critical study. If domestic and industrial water supplies are to be preserved, abatement of pollution of subsurface reservoirs as well as of surface streams will be necessary. Observation wells should be selected and a systematic program of sampling and analysis should be continued for as long a period as necessary to obtain the required data. Some wells will require years of observation. Cooperation should be expected from the oil companies operating in Oklahoma and contiguous States. Thorough studies would provide reliable data

4. Op. cit. 
that would contribute toward avoidance of litigation and towards prevention of the contamination of well-water supplies.

\section{Industrial Utility of Public Water Supplies}

The quality of water used for many public supplies has been reportec' by Smith. ${ }^{4}$ More decailed information and additional complete analyses are needed for some of the supplies already reported. Any report on the chemical character of municipal water supplies is prepared with the expectation that it will be revised from time to time as changes in sources or in treatment of supplies take place. A comprehensive report on public supplies may be prepared by covering portions of the State in considerable detail each year fo: a period of years. The preparation of an adequate report on the chemical character of public water supplies of the State might cost about $\$ 2,000$ each year for a period of three to five years.

\section{TOTAL ANNUAL COSTS AND ANNUAL COST TO OKLAHOMA}

An estimate of the annual cost of a comprehensive quality-of-water program as discussed herein is:

Quality of surface waters:

Comprehensive program $\$ 22,000$

Sediment loads 15,000

Quality of ground waters

Included in ground-water program.

Industrial utility of public water supplies:

Comprehensive progressive report 2,000

Total annual cost $\$ 39,000$

Continuation of present program until start of comprehensive progi im 2,000

Estimated annual costs to the State of Oklahoma under a cooperative agreement with the United States Geological Survey:

Survey:

Oklahoma's half of the program

First year $\$ 20,500$

Annually thereafter 19,500 


\section{WATER UTTLIZATION}

The program of the United States Geological Survey includes analytical and interpretative studies of water facts to increase their utility and to assure that the program shall meet any needs as adequately as possible An essential feature is the compilation of water information and particularly of critical events such as floods and droughts, in a form suited to convenient and effective use in water problems.

Statistical records often require supplemental analysis in order to reveal their significance. The form of the analysis depends largely on the nature of the problem at hand, but it has been found that certain kinds of analyses enter into nearly every water-supply problem. Indeed, the availability of such analyses may encourage, or hold to wise limits, as the case may be, any proposed program which involves water utilization.

"Deficiencies in Hydrologic Research," published by the National Resources Planning Board in 1940, describes the great number of needed investigations, some of which have singular bearing on the surface-water hydrology of Oklahoma. Much ground work needs to be done and only the most preliminary or basic treatments are planned. The most general types of study that can be undertaken are statistical and inventory.

In addition to statistical analyses a great many facts regarding the water resources can be gained from the preparation of a quantitative hydrologic inventory. Such studies consider water in streams not by itself, but as one phase in a cycle containing other intimately related phases and factors including precipitation, interception by vegetation, infiltration, soil moisture, runoff from surface and ground sources, surface and ground storage, evaporation, and transpiration by vegetation. The information developed is useful in many kinds of water problems, particularly in administration of land use and conservation problems, and in flood control. Moreover, it can serve as a basis for estimating stream flow in areas where no stream-gauging station records are available, and as a supplementary method in combination with rainfall records for the synthesis and extension of stream-flow records, especially through critical drought or flood periods.

Some problems which can be advantageously investigated and studied are:

(a) Assembly and compilation in a more usable form of basic information now published annually in water-supply papers. These compilations would save individual users much labor and time consumed in preparing similar compilations for use in their individual problems.

(b) Assembly and compilation of records of maximum stages and discharges which have occurred in Oklahoma and adjacent States. These data are essential for design of spillways, channels, etc., and for use in location of projects above maximum flood levels. 
(c) Preparation of drainage basin or areal reports on the hydrology of those areas giving factual data and interpretative studies on the quality and quantity of the surface and ground-water resources of the area. The type of report contemplated would be similar to those issued by the Oklahoma Geological Survey for Beaver and Cimarron Counties but with a broader scope to cover all the aspects of the quantity, occurrence and quality of surface and ground-water supplies.

(d) Investigations and reports on the water losses from reaches of various streams.

(e) Relations between rainfall and runoff and the effect of antecedent rainfall upon such relations. This study would provide useful relations on extending the short term stream-flow records of Oklahoma into the past.

(f) Average monthly water losses as related to antecedent, and current precipitation. The results of this study would be useful in computing from early precipitation records, supplies of water needed from storage for irrigation purposes during critical periods antedating adequate stream-flow records.

(g) Run-off yields which may be expected from individual storms. This knowledge would be extremely useful in estimating the frequency of and the amount of water supplies available for small storage projects, especially in western Oklahoma where there is practically no sustained runoff and water to be stored must be caught after individual storms.

(h) Evaporation 'osses from open water surfaces of reservoirs. Errors in assumption of the amounts of these losses might very seriously cripple the efficiency and effectiveness of any reservoir.

(i) Investigations and reports on reliable water supplies for stock use. Such information would assist in the selection of a site most favorable to obtaining a reliable supply of water and improve design and construction practices with view to minimizing many of the losses from evaporation, seepage, etc., which may render a supply practically valueless.

It is confidently believed that an annual investment of $\$ 5,000$ in such or allied studies, investigations and reports, would yield dividends in savings to the people of Oklahoma of many times that sum. Under a cooperative agreement with the Jnited States Geological Survey, the annual cost to Oklahoma would be $\$ 2,500$. 


\section{TOPOGRAPHIC MAPPING}

Only a small portion of the State of Oklahoma is covered by adequate maps such as are needed in water-resources investigations in selection of sites for reservoirs, dams, and gauging stations, in examination of geologic structure as related to ground-water occurrence, determination of drainage areas, slopes of streams and many other purposes. The lack of satisfactory maps has been a distinct handicap in many investigations of the United States Geological Survey, Corps of Engineers, Bureau of Reclamation, and many other Federal and State agencies.

It is suggested that a program of topographic mapping should be inaugurated to provide essential map information for carrying forward the investigations and economic studies upon which future developments of State resources are dependent. It is thought that such a program of mapping should be sufficiently large to provide maps of selected areas at a rate that is commensurate with the anticipated progress in engineering and economic developments. The cost of topographic mapping, to the State, would be only one half of the actual total cost of the maps, if the project is undertaken in cooperation with the United States Geological Survey which is authorized to match State offerings, on a dollar for dollar basis, provided the topographic surveys are designed to result in maps for peblication on the scales of $1: 62,500$, approximately one inch to a mile, or $1: 31,680$ on which one inch equals onehalf mile.

Subject to the appropriation of Federal funds for the purpose, the Geological Survey will match any offering of the State for cooperative topographic surveys. However, it is thought that the annual offering of the State of Oklahoma should not be less than $\$ \mathbf{2 5 , 0 0 0}$ to assure an orderly and economical program and to provide essential map information at a rate that will serve the more urgent requirements. As has been stated, the total amount available annually for topographic mapping would be increased to two times the annual offering of the State by an equal offering of Federal funds from the appropriation for the Geological Survey, if undertaken as a cooperative project.

Approximately two-thirds of the topographic mapping, that is now considered to be adequate in quality for present requirements, has resulted from surveys carried on, in earlier years, in cooperation with the Territorial Survey Commission, the State Geological Survey, and the State Highway Commission. Cooperation with the State Highway Commission was authorized by the State in House Bill No. 340, approved by the Governor on March 31, 1927. 